\title{
ALOKASI DANA CSR SEBAGAI VARIABEL MODERASI ANTARA PENERAPAN GOOD CORPORATE GOVERNANCE (GCG) TERHADAP NILAI PERUSAHAAN PADA SUB SEKTOR PERBANKAN
}

\author{
Basir. S \\ Sekolah Kajian Stratejik dan Global \\ Universitas Indonesia, Salemba-Jakarta \\ Email: basir@ui.ac.id
}

\begin{abstract}
Corporate value is influenced by many factors, one of which is through Good Corporate Governance. Corporate governance is a system that regulates and controls companies that are expected to provide and increase the value of the company to shareholders. The allocation of Corporate Social Responsibility funds is selected as a moderating variable because Corporate Social Responsibility activities are part of good corporate governance that is expected to strengthen Good Corporate Governance relationship with company value. The population in this study is the banking subsector companies listed on the BEI. Sampling technique using purposive sampling and based on predetermined criteria then the number of 22 samples of companies subsector banking. This research followed by the analysis by using Regression Moderation analysis. The result of the research shows that the implementation of Good Corporate Governance proxied with the Proportion of Independent Commissioners , Audit Committee, Independence Audit Committee , Frequency of Audit Committee Meeting and Frequency of Meeting of Board of Commissioner simultaneously have significant effect to company Value with CSR as moderation.
\end{abstract}

Keywords: Good Corporate Governance, Corporate Value, Corporate Social Responsibility 


\begin{abstract}
Abstrak
Nilai perusahaan dipengaruhi oleh banyak faktor, salah satunya adalah Good Corporate Governance. Tata kelola perusahaan adalah sistem yang mengatur dan mengendalikan perusahaan yang diharapkan dapat memberikan dan meningkatkan nilai perusahaan kepada pemegang saham. Alokasi dana Tanggung Jawab Sosial Perusahaan dipilih sebagai variabel moderasi karena kegiatan Tanggung Jawab Sosial Perusahaan adalah bagian dari tata kelola perusahaan yang baik yang diharapkan dapat memperkuat hubungan Good Corporate Governance dengan nilai perusahaan. Populasi dalam penelitian ini adalah perusahaan subsektor perbankan yang terdaftar di BEI. Teknik pengambilan sampel menggunakan purposive sampling dan berdasarkan kriteria yang telah ditentukan dan didapatkan jumlah sampel 22 perusahaan perbankan subsektor. Penelitian ini dilanjutkan dengan analisis dengan menggunakan analisis Regresi Moderasi. Hasil penelitian menunjukkan bahwa penerapan Good Corporate Governance diproksikan dengan Proporsi Komisaris Independen, Komite Audit, Komite Audit Independen, Frekuensi Rapat Komite Audit dan Frekuensi Rapat Dewan Komisaris secara simultan berpengaruh signifikan terhadap Nilai Perusahaan dengan CSR sebagai moderasi.
\end{abstract}

Kata Kunci : good corporate governance, nilai perusahaan, tanggung jawab sosial 
Basir S, Alokasi Dana CSR Sebagai Variabel Moderasi Antara...

\section{PENDAHULUAN}

Corporate Governance (CG) sudah menjadi topik bahasan utama di bisnis global seiring dengan meningkatnya komplektifitas dan tekanan persaingan bisnis yang dihadapi perusahaan. Berbagai skandalorporasi/ perusahaanbesar, diantaranyaEnron dan Parmalat, menjadikan dunia internasional semakin mencurahkan perhatian tergadap Corporate Governance. Skandal-skandal korporasi tersebut menunjukkan bahwa organ-organ perusahaan belum dapat melaksanakan fungsi,tugas,dan tanggung jawabnya secara baik. Di Indonesia, terjadinya krisis ekonomi berisiko tinggi menimbulkan krisis dimensi sebagaimana pernah terjadi tahun 1997. Resiko ini ditengarai karena ketidak optimalan perusahaan-perusahaan Indonesia dalam penerapan Corporate Governance (Warsono dan Amalia, 2009:1).

Sejak krisis ekonomi tahun 1997 pelaksanakan tata kelola perusahaan yang baik, atau lebih kenal dengan Good Corporate Governance (GCG) menjadi isu yang hangat di Indonesia. Akibat buruknya tata kelola pemerintah dan perusahaan di Indonesia pada masa itu, menyebabkan perekonomian Indonesia menjadi terpuruk. Semenjak itulah, semua pihak sepakat untuk dapat bangkit dari keterpurukan, Indonesia harus memulai dengan tata kelola yang baik bagi pemerintah, perusahaan pemerintah dan swasta. Berbagai upaya memperbaiki tata kelola dilakukan dengan menerapkan prinsip Good Corporate Governance disemua lini masyarakat (Zarkasyi,2008:1).

Berdirinya sebuah perusahaan harus memiliki tujuan yang jelas. Ada beberapa tujuan berdirinya sebuah perusahaan. Tujuan yang pertama adalah untuk mencapai keuntungan maksimal. Tujuan yang kedua adalah ingin memakmurkan pemilik perusahaan atau para pemilik saham. Sedangkan tujuan ketiga adalah memaksimalkan nilai perusahaan yang tercermin padaharga saham. Ketiga tujuan perusahaan tersebut sebenarnya secara substansial tidak hanya berbeda. Hanya saja penekanan yang ingin dicapai oleh masing-masing perusahaan berbeda antara yang satu dengan lainnya (Martono dan Harjito,2005:2)

Good Corporate Governance memiliki banyak definisi, Forum For Corporate Governance in Indonesia (FCGI) mendefinisikan corporategovernance sebagai seperangkat peraturan yang menetapkan hubungan antar pemegang saham, pengurus, pihak kreditur, pemerintah, karyawan, serta para pemegang kepentingan intern dan ekstern lainnya sehubungan dengan hak-hak dan kewajiban mereka,atau dengan kata lain sistem yang mengarahkan dan mengendalikan perusahaan. Di kalang pebisnis,secara umum Good Corporate Governance diartikan sebagaitata kelola perusahaan. Good Corporate Governancediartikan pula sebagai sistem yang mengatur dan mengendalikan perusahaan yang menciptakan nilai tambah (value added) untuk semua stakeholder (Monk,2003).

Secara lebih rinci, terminologi Corporate Governance dapat dipergunakan untuk menjelaskan peranan dan perilaku dari dewan direksi, dewan komisaris, pengurus perusahaan,dan para pemegang saham(Susanti,2010).

Ada beberapa kasus tentang kurangnya penerapan Good Corporate Goverment perusahaan perbankan 
diantaranya : Kebobolan kredit fiktif miliaran rupiah. Hal ini bermula dari pengajuan kredit terkait suatu proyek oleh sebuah CV sebesar Rp 9,4 miliar. Namun yang disetujui hanya Rp 4,8 miliar dan dalam proses pembayarannya mengalami kemacetan, kredit macetnya sebesar Rp 3,4 miliar. Belakangan diketahui bahwa surat perintah kerja terkait kredit tersebut ternyata dipalsukan. Nilai proyeknya pun sangat jauh lebih kecil dibandingkan dengan pengajuan kreditnya, yakni hanya Rp 92 juta (Sumber : www.kilasberita.com).

Korupsi dilakukan mantan Direktur Utama salah satu Bank. Terdakwa dianggap secara sah dan menyakinkan terbukti bersalah merugikan negara sebesar Rp 51 miliar. Salah satu perbuatannya ialah meminta pimpinan bank anak cabang menyetorkan dana untuk komisi dari modal tetapi tanpa bukti administrasi berupa penerimaan. Perbuatan ini dinilai hakim melawan hukum formil, yakni undang-undang dan perbuatan tercela melawan hukum secara materi (Sumber :www.liputan6.com)

Dari permasalahan tersebut menunjukan bahwa masih lemahnya pengelolaan risiko dan penerapan prinsipprinsip Good

Corporate

Governance (GCG) di lingkungan Perbankan. . Permasalahan tersebut bisa menurunkan tingkat kepercayaan nasabah, berpengaruh pada harga saham dan juga pada kepercayaan mitra untuk melakukan transaksi bisnis. Tidak dapat dipungkiri bahwa nama baik perusahaan merupakan salah satu aset yang paling berharga, terlebih lagi untuk industri perbankan yang dasarnya adalah kepercayaan antara penyimpan dana dan penghimpun dana.
Nilai perusahaan yaitu sebagai nilai pasar karena nilai perusahaan dapat memberikan kemakmuran pemegang saham secara maksimum apabila harga saham perusahaan meningkat. Berbagai kebijakan yang telah diambil oleh manajemen dalam upaya untuk meningkatkan nilai perusahaan melalui peningkatan kemakmuran pemilik dan para pemegang saham yang tercermin pada harga saham. (Brigman \& Houston, 2006:19)

Menurut Alfredo (2011) ada beberapa faktor yang mempengaruhi nilai perusahaan, yaitu: keputusan pendanaan, tata kelola perusahaan yang baik, kebijakan deviden, keputusan investasi, struktur modal, pertumbuhan perusahaan, ukuran perusahaan.

Nilai perusahaan dapat menunjukkan nilai asset yang dimiliki perusahaan seperti surat-surat berharga. Saham merupakan salah satu asset berharga yang dikeluarkan oleh perusahaan (Martono \& Agus, 2003:3). Nilai perusahaan yang tinggi dapat meningkatkan kemakmuran bagi para pemegang saham, sehingga para pemegang saham akan menginvestasikan modalnya kepada perusahaan tersebut (Haruman,2008). Nilai perusahaan dipengaruhi oleh banyak faktor, salah satunya adalah melalui tata kelola perusahaan yang baik atau Good Corporate Governance(Arfianty,2015). Corporate Governance merupakan suatu sistem yang mengatur dan mengendalikan perusahaan yang diharapkan dapat memberikan dan meningkatkan nilai perusahaan kepada para pemegang saham ( Shleifer dan Vishny, 1997). Good Corporate Governance dapat dikatakan dapat menciptakan nilai tambah karena 
Basir S, Alokasi Dana CSR Sebagai Variabel Moderasi Antara...

dengan menerapkan Good Corporate Governance, diharapkan perusahaan akan memiliki kinerja yang baik sehingga dapat menciptakan nilai tambah dan meningkatkan nilai perusahaan yang dapat memberikan keuntungan bagipara pemegang saham atau pemilik perusahaan.

Profit merupakan salah satu indikator keberhasilan perusahaan dalam menjalankan bisnisnya. Namun terdapat indikator lain selain profit yang diperlukan perusahaan untuk bertahan di masa mendatang. Tanggung jawab perusahaan terhadap lingkungan sosial juga menjadi salah satu indikator penting. Karena menurut Eipstein dan Freedman (1994) investor tidak hanya memperhatikan besarnya profit, namun juga informasi sosial yang dilaporkan dalam laporan tahunan. Informasi sosial ini mencangkup laporan pelaksanaa tanggung jawab sosial perusahaan terhadap masyarakat. Corporate Social Responsibilityadalah tanggungjawab perusahaan terhadap masyarakat diluar tanggungjawab ekonomis. Jika berbicara tanggungjawab perusahaan, yang dimaksud adalah kegiatan-kegiatan yang dilakukan perusahaan demi suatu tujuan sosial dengan tidak memperhitungkan untung dan rugi (Simorangkir,2003:55).

Keberlanjutan perusahaan hanya akan terjamin apabila perusahaan memperhatikan dimensi sosial dan lingkungan hidup. Sudah menjadi fakta bagaimana resistensi masyarakat sekitar, diberbagai tempat dan waktu muncul ke permukaan terhadap perusahaan yang dianggap tidak memerhatikan aspekaspek sosial,ekonomi dan lingkungan hidupnya (Kusumadilaga,2010). Dengan menerapkan Corporate Social
Responsibility, perusahaan dapat menciptakan citra yang baik bagi perusahaan sehingga menimbulkan penilaian positif dari konsumen yang mampu meningkatkan loyalitas mereka terhadap produk yang dihasilkan perusahaan. Semakin baik alokasi dana CSR maka akan berdampak pada peningkatan nilai tambah bagi perusahaan.

Selain itu perusahaan akan memperoleh legitimasi sosial dan memaksimalkan kekuatan keuangannya dalam jangka panjang melalui penerapan CSR (Kiroyan,2006:45). Penerapan CSR ini selain akan menguatkan citra perusahaan, diharapkan akan memberi dampak positif, pada pendapatan perusahaan pada umumnya sehingga investasi kepada perusahaan akan terjaga.

Salah satu wujud pelaksanaan prinsip Good Corporate Governance merupakan implementasi Corporate Social Responcibility (CSR). McWilliams dan Siegel (2001) mendefinisikan CSR sebagai aksi yang muncul sebagai lanjutan dari tindakan sosial,melebihi kepentingan perusahaan dan diwajibkan oleh hukum. Penerapan Good Corporate Governance memiliki kaitan erat dengan Corporate Social Responcibility untuk memengaruhi nilai suatu perusahaan, karena para investor akan lebih tertarik menginvestasikan modalnya apabila terdapat CSR pada suatu perusahaan.

Selanjutnya, Corporate Social Responcibility dipilih sebagai variabel moderasi karena kegiatan Corporate Social Responcibility merupakan bagian dari tata kelola perusahaan yang baik yang diharapkan mampu memperkuat hubungan Good Corporate Governance dengan nilai perusahaan. Akan tetapi 
tidak menutup kemungkinan hal tersebut hanya terjadi pada perusahaan-perusahaan tertentu karena kondisi tiap perusahaan berbeda, baikdari segi visi,misi, segmen pasar maupun manajemen perusahaan yang memungkinkan bahwa penerapan Corporate Social Responcibility maupun Good Corporate Governance justru tidak berpengaruh terhadap peningkatan nilai perusahaan.

Tabel 1.1

Tabel Daftar Penerima Indonesia Good Corporate Award 2015

\begin{tabular}{|c|c|}
\hline $\begin{array}{l}\text { 1. The } \\
\text { Best } \\
\text { Overall }\end{array}$ & $\begin{array}{l}\text { 1. PT. Bank Danamon } \\
\text { Indonesia Tbk. } \\
\text { 2. PT. Bank CIMB Niaga Tbk. } \\
\text { 3. PT. Aneka Tambang Tbk. }\end{array}$ \\
\hline $\begin{array}{l}\text { 2. The } \\
\text { Best } \\
\text { Financial } \\
\text { Sector }\end{array}$ & $\begin{array}{l}\text { 1. PT. Bank Tabungan Negara } \\
\text { Tbk. } \\
\text { 2. PT. Bank Mandiri Indonesia } \\
\text { Tbk. } \\
\text { 3. PT. Bank Rakyat } \\
\text { IndonesiaTbk. }\end{array}$ \\
\hline $\begin{array}{l}\text { 3. The } \\
\text { Best Non } \\
\text { Financial } \\
\text { Sector }\end{array}$ & $\begin{array}{l}\text { 1. PT. Indo Tambangraya } \\
\text { Megah Tbk. } \\
\text { 2. PT. XL Axiata Tbk. } \\
\text { 3. PT. Jasa Marga Tbk. }\end{array}$ \\
\hline $\begin{array}{l}\text { 4. The } \\
\text { Best } \\
\text { State } \\
\text { Owned } \\
\text { Entrepris } \\
\text { e }\end{array}$ & $\begin{array}{l}\text { 1. PT. Bank Negara Indonesia } \\
\text { Tbk. } \\
\text { 2. PT. Telkom Tbk. } \\
\text { 3. PT. Wijaya Karya Tbk. }\end{array}$ \\
\hline $\begin{array}{l}\text { 5. The } \\
\text { Best } \\
\text { Responsi } \\
\text { bility of } \\
\text { the } \\
\text { Board }\end{array}$ & $\begin{array}{l}\text { 1. PT. Bank OCBC NISP Tbk. } \\
\text { 2. PT. Bank Central Asia Tbk. }\end{array}$ \\
\hline $\begin{array}{l}\text { 6. The } \\
\text { Best } \\
\text { Disclosur } \\
\text { e and } \\
\text { Transpar } \\
\text { ancy }\end{array}$ & $\begin{array}{l}\text { 1.PT. Bank Permata Tbk. } \\
\text { 2. PT. Bank Maybank } \\
\text { Indonesia Tbk. }\end{array}$ \\
\hline $\begin{array}{l}\text { 7. The } \\
\text { Best }\end{array}$ & $\begin{array}{l}\text { 1. PT. Bank Pan Indonesia } \\
\text { Tbk. }\end{array}$ \\
\hline
\end{tabular}

\begin{tabular}{|c|c|}
\hline $\begin{array}{l}\text { Equitable } \\
\text { Treatme } \\
\text { nt of } \\
\text { Sharehol } \\
\text { ders }\end{array}$ & 2. PT. Astra Internasional Tbk. \\
\hline $\begin{array}{l}\text { 8. The } \\
\text { Best } \\
\text { Right of } \\
\text { Sharehol } \\
\text { ders }\end{array}$ & $\begin{array}{l}\text { 1. PT. Garuda Indonesia Tbk. } \\
\text { 2. PT. Saratoga Investama } \\
\text { Sedata Tbk. }\end{array}$ \\
\hline $\begin{array}{l}\text { 9. The } \\
\text { Best Role } \\
\text { of } \\
\text { Stakehol } \\
\text { ders }\end{array}$ & $\begin{array}{l}\text { 1. PT. Perusahaan Gas Negara } \\
\text { Tbk. } \\
\text { 2. PT. Bank Tabungan Pensiun } \\
\text { Nasional Tbk. }\end{array}$ \\
\hline
\end{tabular}

perbankankarena bank telah menduduki posisi yang dominan dalam sistem pertumbuhan dan juga di jelaskan pada tabel diatas pada penghargaan Indonesia Good Corporate Award 2015 juga posisi The Best Overall di tempati oleh perusahaan perbankan. Selain itu terdapat perbedaan karakteristik antara perusahaan perbankan dan perusahaan lainnya, dan juga karena perusahaan baik perbankan dan non perbankan, manajer wajib dalam melaporkan kinerja perusahaan melalui tata kelola perusahaan yang baik. Selain itu perbankan berpengaruh langsung terhadap lingkungan dan masyarakat sekitar sehingga memiliki tingkat sensitifitas yang tinggi terhadap setiap kejadian baik internal maupun ekternal pada perusahaan. Bank harus mampu menjaga kualitas yang baik agar dipercaya oleh para nasabahnya dan berpengaruh terhadap likuiditas bank. Oleh karena itu, peneliti memasukkan alokasi dana Corporate Social Responsibility (CSR) sebagai variabel moderasi. Dalam penelitian ini Corporate Social Responsibility (CSR) di ukur 
Basir S, Alokasi Dana CSR Sebagai Variabel Moderasi Antara...

dengan menggunakan informasi mengenai alokasi dana CSR.

Motivasi penelitian ini adalah adanya perbedaan hasil penelitian yang telah dilakukan oleh peneliti sebelumnya terdapat ketidakkonsistenan hasil penelitian antara hubungan Good Corporate Governance dan nilai perusahaan dengan Corporate Social Responsibility, sehingga peneliti ingin menguji kembali. Selain itu, penelitian ini menggunakan objek yang berbeda yaitu sub sektor perbankan di BEI periode 2015-2017. Periode yang diambil hanya 2 tahun karena sampel data sudah cukup yaitu 50, karena minimal sampel 30 (Mahmud,2011). Tujuan dalam penelitian ini adalah untuk mengetahui pengaruh Good Corporate Governance terhadap nilai perusahaan perbankan yang terdaftar di BEI serta pengaruh Corporate Social Responsibility mampu memoderasi Good Corporate Governance terhadap nilai perusahaan perbankan yang terdaftar di BEI.

\section{LANDASAN TEORI}

\section{Pengertian dan Konsep Dasar Good Corporate Governance (GCG)}

Dua teori utama yang terkait dengan Corporate Governance adalah steward theory dan agency theory. Steward theory dibangun di atas asumsi filosofis mengenai sifat manusia yakni bahwa manusia pada hakikatnya dapat dipercaya, mampu bertindak dengan penuh tanggung jawab, memiliki integritas dan kejujuran terhadap pihak lain. Inilah yang tersirat dalam hubungan fidusia yang dikehendaki para pemegang saham. Dengan kata lain, steward theory memandang manajemen sebagai dapat dipercaya untuk bertindak dengan sebaikbaiknya bagi kepentingan public maupun stakeholder. Sementara itu, agency theory yang dikembangkan oleh Jensen, M.C., and W. H. Meckling (1976) memandang bahwa manajemen perusahaan sebagai "agents" bagi para pemegang saham, akan bertindak dengan sepenuh kesadaran bagi kepentingan sendiri, bukan sebagai pihak yang arif dan bijaksana serta adil terhadap pemegang saham.

Zarkasyi (2008:36) mendifinisikan Good Corporate Governancepada dasarnya merupakan suatu sistem (input, proses, output) dan seperangkat peraturan yang mengatur hubungan antara berbagai pihak yang berkepentingan (stakeholder) terutama dalam arti sempit hubungan antara pemegang saham, dewan komisaris, dan dewan direksi demi tercapainya tujuan perusahaan.

\section{Tujuan dan Manfaat Good Corporate Governance}

Good Corporate Governance
memeberikan kerangka acuan yang memungkinkan pengawasan berjalan efektif sehingga tercipta mekanisme check and balances pada perusahaan, ada beberapa manfaat yang diperoleh yakni Jojok (2009) :

a. Mengurangi agency cost, yaitu suatu biaya yang harus ditanggung pemegang saham sebgaai akibat pendelegasian wewenang kepada pihak manajemen. Biaya-biaya ini dapat berupa kerugian yang diderita perusahaan sebagai akibat penyalahgunaan wewenang, ataupun berupa biaya pengawasan yang timbul untuk mencegah terjadinya hal tersebut. 
b. Mengurangi biaya modal, yaitu sebagai dampak dari pengelolaan perusahaan yang baik tadi menyebabkan tingkat bunga atas dana atau sumber daya yang dipinjam oleh perusahaan semakin kecil seiring dengan turunnya tingkat risiko perusahaan.

c. Meningkatkan nilai saham perusahaan sekaligus dapat meningkatkan citra perusahaan tersebut kepada publik luas dalam jangka panjang.

d. Menciptakan dukungan para stakeholder dalam lingkungan perusahaan tersebut terhadap keberadaan dan berbagai strategi dan kebijakan yang ditempuh perusahaan, karena umumnya mereka mendapat jaminan bahwa mereka juga mendapat manfaat maksimal dari segala tindakan dan operasi perusahaan dalam menciptakan kemakmuran dan kesejahteraan.

\section{Pengukuran Nilai Perusahaan}

$\quad$ Dalam penelitian
pengukuran nilai penulis
menggunakan
Price Book Value (PBV)

Book Value (PBV) banyak digunakan dalam pengambilan keputusan investasi. Menurut Atmaja (2008: 417) Price Book Value (PBV) dapat dihitung dengan rumus sebagai berikut:

\section{PBV = Harga Pasar Saham / Nilai Buku Per Lembar Saham}

Berdasarkan pendekatan konsep nilai pasar atau Price to Book Value tersebut, harga saham dapat diketahui berada diatas atau dibawah nilai bukunya. Pada dasarnya, membeli saham berarti membeli prospek perusahaan. PBV yang tinggi akan membuat investor yakin atas prospek perusahaan dimasa mendatang.
Oleh karena itu keberadaan rasio PBV sangat penting bagi para investor maupun calon investor untuk menetapkan keputusan investasi.

\section{Corporate Social Responsibility}

Corporate Social Responsibility adalah tanggungjawab perusahaan terhadap masyarakat diluar tanggungjawab ekonomis. Jika berbicara tanggungjawab perusahaan, yang dimaksud adalah kegiatan-kegiatan yang dilakukan perusahaan demi suatu tujuan sosial dengan tidak memperhitungkan untung dan rugi (Simorangkir,2003:55). Sedangkan menurut Darwin (2004) Corporate Social Responsibilitydiartikan sebagai mekanisme bagi suatu perusahaan untuk secara sukarela mengintegrasikan perhatian terhadap lingkungan sosial kedalam operasinya dan interaksinya dengan stakeholder, yang melebihi tanggungjawab sosial dibidang hukum.

Konsep tanggungjawab sosial perusahaan telah mulai dikenal sejak tahun 1979 yang secara umum diartikan kumpulan kebijakan dan praktek yang berhubungan dengan stakeholder, nilainilai pemenuhan hukum, penghargaan masyarakat terhadap lingkungan serta komitmen dunia usaha. Pearce dan Robinson (2007) menyebutkan ada sepuluh pihak yang berkepentingan terhadap perusahaan yang masing-masing mempunyai kepentingan berbeda dan cara pandang yang berbeda terhadap perusahaan. Kesepuluh pihak yang dimaksud adalah stakeholders, creditor, employees, customers, suppliers, goverments, unions, competitors, local communities, general public. 
Basir S, Alokasi Dana CSR Sebagai Variabel Moderasi Antara...

Kerangka Konseptual

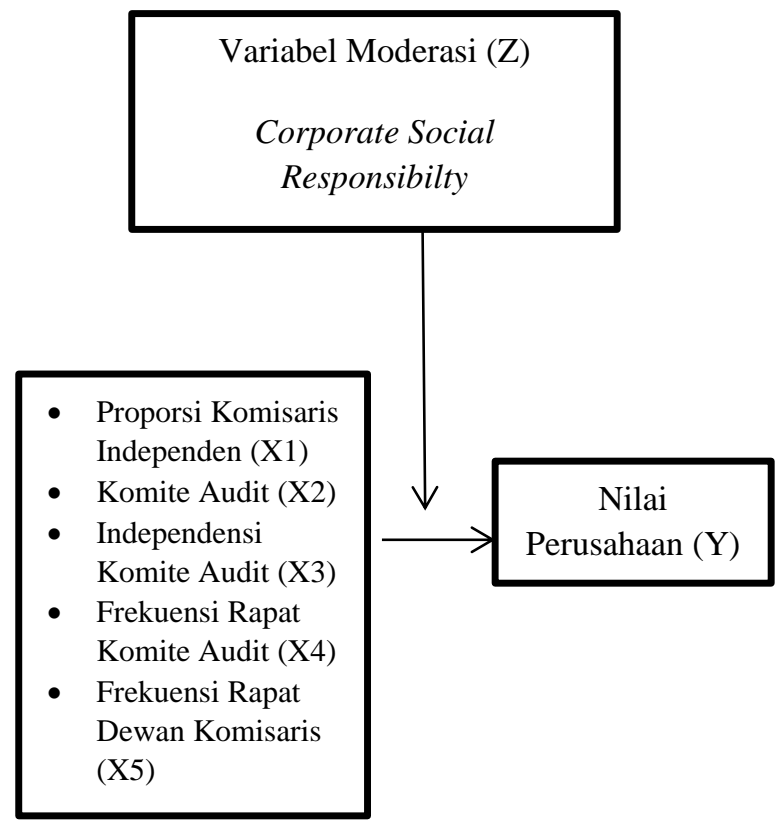

\section{HIPOTESIS}

Dari beberapa penelitian yang telah dilakukan terlihat bahwa Good Corporate Governance pengaruh diantara keduanya. Berdasarkan hasil penelitian tersebut, maka hipotesis yang diajukan adalah:

H1 : Good Corporate Governance berpengaruh terhadap nilai perusahaan

H2 : Corporate Social Responsibility mampu memoderasi Good Corporate Governance terhadap nilai perusahaan

\section{METODE PENELITIAN}

Jenis pendekatan yang digunakan adalah penelitian kuantitaif deskriptif. Populasi dalam penelitian ini sebanyak 43 perusahaan perbankan yang terdaftar di Bursa Efek Indonesia periode 2015-2017. Sampel penelitian ini adalah perusahaan perbankan yang melaporkan alokasi dana Corporate Social Responsibility pada tahun 2015-2017. Di Indonesia sebanyak
25 perusahaan perbankan yang melaporkan di laporan tahunan.

Pengambilan sampel dilakukan dengan purposive sampling. Variabel terikat adalah variabel yang dalam penelitian tergantung atau dipengaruhi oleh variabel bebas.

\section{Definisi Operasional Variabel}

Dalam penelitian ini yang menjadi variabel terikat (Y) adalah Nilai Perusahaan.

Nilai perusahaan disini diukur dengan PBV (Price to Book Value) merupakan salah satu variabel yang dipertimbangkan seorang investor dalam menentukan saham mana yang akan dibeli. Semakin besar rasio PBV semakin tinggi perusahaan dinilai oleh para pemodal relatif di bandingkan dengan dana yang telah ditanamkan diperusahaan. PBV dihitung dengan rumus sebagai berikut (Atmaja,2008:417):

PBV = Harga Pasar Saham / Nilai Buku Per Lembar Saham

Good Corporate Governance

1. Menghitung Proporsi komisaris independen menggunakan rumus (Sudibyo,2013):

Komisaris Independen X 100\%

Total Dewan Komisaris

2. Menghitung Komite audit diukur dengan jumlah anggota komite audit (Sam'ani,2008).

3. Menghitung proporsi jumlah anggota komite audit independen dan jumlah seluruh 
anggota komite audit (Sam'ani,2008).

Jumlah anggota audit independen Jumlah seluruh anggota komite audit

4. Menghitung Frekuensi Rapat Komite Audit diukur dengan jumlah rapat komite audit. (Dewayanto,2010):

Frekuensi Rapat Komite Audit = Jumlah Rapat Komite Audit

\section{Menghitung Frekuensi Rapat Dewan Komisaris diukur dengan jumlah rapat dewan komisaris. (Dewayanto,2010);}

Frekuensi Rapat Dewan Komisaris =

Jumlah rapat dewan komisaris

komisaris

\section{Corporate Social Responsibility}

Corporate Social Responsibility (CSR) dalam penelitian ini diukur melalui rumus yang digunakan adalah:

CSR = Logarithm natural dana CSR tahun t......... Basir (2015)

\section{Model Analisis Data}

Alat uji yang digunakan dalam pengujian penelitian ini adalah Uji Hipotesis menggunakan Uji Koefisien Determinasi, t-test dan Moderated Regression Analysis (MRA). Pengujian ini dilakukan dengan membuat regresi interaksi, tetapi variabel moderator tidak berfungsi sebagai variabel independen. Apabila hasil uji ini beta yang dihasilkan dari interaksi ZX terhadap $\mathrm{Y}$ menghasilkan nilai negatif, maka variabel moderasi $\mathrm{Z}$ memperlemah pengaruh variabel $\mathrm{X}$ terhadap variabel $\mathrm{Y}$, meskipun memperlemah tetapi pengaruhnya tidak signifikan, begitu juga sebaliknya, jika beta menghasilkan positif, maka variabel moderasi $\mathrm{Z}$ memperkuat pengaruh variabel $X$ terhadap variabel $\mathrm{Y}$.

\section{HASIL DAN PEMBAHASAN}

\section{Pengaruh Good Corporate Governance Terhadap Nilai Perusahaan}

Berdasarkan hasil uji signifikansi di peroleh hasil bahwa Good Corporate Governance yang diproksikan proporsi komite audit, komite audit, independensi komite audit, frekuensi rapat komite audit, frekuensi rapat dewan komisaris berpengaruh signifikan terhadap PBV. Hasil uji tersebut sejalan dengan teori yang mengatakan bahwa penerapan prinsip Good Corporate

Governance dalam dunia usaha merupakan suatu kebutuhan dalam menjalankan aktivitas bisnis perusahaan yang ada dapat terus bersaing serta bertahan dalam persaingan pasar global yang semakin kompetitif sehingga perusahaan dapat mencapai tujuannya. Salah satu tujuan dari perusahaan adalah meningkatkan kesejahteraan pemilik atau pemegang saham atau memaksimalkan kekayaan pemegang saham melalui peningkatan nilai perusahaan (Brigham \& Housten, 2006). Hasil penelitian ini juga sejalan dengan penelitian yang dilakukan oleh Nuswandari (2009),Kusumadilaga (2010), dan Mutmainah (2015) mempunyai persamaan yaitu meneliti 
Basir S, Alokasi Dana CSR Sebagai Variabel Moderasi Antara...

mengenai pengaruh secara langsung terhadap GCG. Dan sesuai dengan pedoman GCG yang merupakan acuan bagi perusahaan, dengan melakukan GCG dapat mengoptimalkan nilai perusahaan bagi pemegang saham dengan tetap memperhatikan pemangku kepentingan lainnya.

Jojok (2009) mengatakan bahwa manfaat dari Good Corporate Governance adalah untuk meningkatkan nilai saham perusahaan sekaligus dapat meningkatkan citra perusahaan tersebut kepada publik luas dalam jangka panjang. Teori ini sejalan dengan teori Eka(2014) yang mengatakan bawa secara bersamasama Good Corporate Governance memiliki pengaruh kepada nilai perusahaaan.

Nilai perusahaan yang tinggi menggambarkan bahwa kinerja perusahaan dalam keadaan baik dan dapat menunjukkan tata kelola perusahaan yang optimal pula sehingga dapat menguntungkan perusahaan. Rata- rata yang telah terdapat pada nilai perusahaan tahun 2017 meningkat pesat . Oleh karena itu semakin baik tata kelola suatu perusahaan maka pihak investor juga akan tertarik berinvestasi karena mengetahui prospek yang baik.

Jika dilihat dari perspektif islam, hal tersebut sesuai dengan firman Allah surat Al-Anfal ayat 27 yang berbunyi:

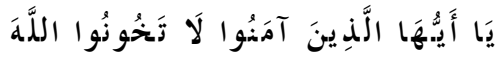

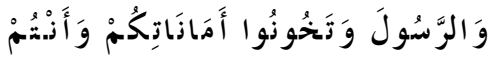

$$
\begin{aligned}
& \text { تَعََْْْمُونَ نَ }
\end{aligned}
$$

Artinya: "Hai orang-orang yang beriman, janganlah kamu mengkhianati Allah dan Rasul (Muhammad) dan (juga) janganlah kamu mengkhianati amanatamanat yang dipercayakan kepadamu, sedang kamu mengetahui."

Dari Al-Quran surat Al-anfal ayat 27 dijelaskan bahwa setiap individu harus mempunyai pertanggungjawaban dalam setiap amanah yang diberikan kepadanya.

Pengaruh Alokasi Dana Corporate Social Responsibility Sebagai Variabel Moderasi dalam hubungan antara Good Corporate Governance dengan Nilai Perusahaan

Hasil pengujian hipotesis dengan menggunakan SPSS ditemukan bahwa variabel Alokasi Dana CSR dapat memoderasi hubungan profitabilitas dan nilai perusahaan. Hal tersebut dapat dikatakan variabel moderator (Z) berinteraksi dengan variabel independen (X) dan juga berhubungan dengan variabel dependen $(\mathrm{Y})$.

Ancok (2005:24) mengatakan bawha manfaat apabila menjalankan CSR adalah dapat mempertinggi reputasi perusahaan dan corporate branding.

Alokasi dana CSR mampu meningkatkan nilai perusahaan. Desakan lingkungan perusahaan menuntut perusahaan agar menerapkan strategi untuk memaksimalkan nilai perusahaan. Strategi perusahaan seperti CSR dapat dilakukan untuk memberikan image perusahaan yang baik kepada pihak eksternal. Perusahaan dapat memaksimalkan modal pemegang saham, reputasi perusahaan, dan kelangsungan hidup jangka panjang perusahaan dengan menerapkan CSR. Telah disebutkan dalam UU bahwa perusahaan yang aktivitasnya berhubungan dengan lingkungan alam wajib menerapkan CSR. 
Perusahaan tidak hanya memandang laba sebagai satu-satunya tujuan dari perusahaan tetapi ada tujuan yang lainnya yaitu kepedulian perusahaan terhadap lingkungan, karena perusahaan mempunyai tanggung jawab yang lebih luas dibanding hanya mencari laba untuk pemegang saham (Gray et. al. 2008; 77)

Semakin baik corporate social responsibility (CSR) dan good corporate governance (GCG) maka nilai perusahaan juga akan meningkat atau sebaliknya. Hal ini mengindikasikan bahwa semakin baik perusahaan melaksanakan corporate social responsibility (CSR) dan good corporate governance (GCG) terhadap masyarakat maupun sumber daya manusia serta pemegang saham akan dapat meningkatkan nilai perusahaan McWilliams dan Siegel (2001). Hasil penelitian ini sejalan dengan penelitian Eka (2014) yang mengatakan bahwa CSR saat ini menjadi isu penting berkaitan dengan masalah dampak bagi lingkungan dalam pembangunan yang berkelanjutan. Hal ini muncul karena banyak kerusakan lingkungan baik fisik, psikis maupun sosial. oleh karena itu peran CSR bagi perusahaan sangat penting.

Penelitian Mutmainah (2015) juga mengatakan Corporate Social Responsibility mampu memoderasi Good Corporate Governance dan nilai perusahaan. Dengan menerapkan Corporate Social Responsibility, perusahaan dapat menciptakan citra yang baik bagi perusahaan sehingga menimbulkan penilaian positif dari konsumen yang mampu meningkatkan loyalitas mereka terhadap produk yang dihasilkan perusahaan. Semakin baik alokasi dana CSR maka akan berdampak pada peningkatan nilai tambah bagi perusahaan.
Dilihat juga dari rata-rata pertumbuhan CSR pada perusahaan perbankan dari tahun 2015-2017 mengalami kenaikan. Itu artinya persahaan perbankan menjalankan CSR di masing-masing perusahaan denganoptimal. dengan demikian keberlanjutan perusahaan akan terjamin kedepannya.

Jika dilihat dari perspektif islam hal ini sejalan dengan ayat Al-Baqarah ayat 245 yang berbunyi :

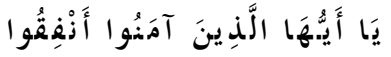

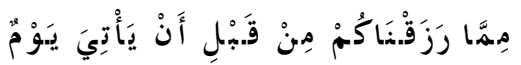

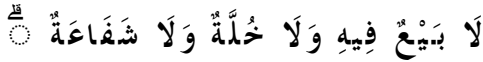

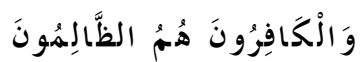

Artinya : "Hai orang-orang yang beriman, belanjakanlah (di jalan Allah) sebagian dari rezeki yang telah Kami berikan kepadamu sebelum datang hari yang pada hari itu tidak ada lagi jual beli dan tidak ada lagi syafa'at. Dan orangorang kafir itulah orang-orang yang zalim."

Berbagi bermakna memberikan apa yang dimiliki seseorang kepada orang lain. Selain itu, menurut Meutia (2010), berbagi juga dimaknai sebagai berbagi hal yang non-materiil, seperti berbagi kebaikan serta menjalankan amar ma'ruf nahi munkar (saling menasehati dalam kebaikan dan mencegah kejahatan). Dalam praktik perbankan syariah, hal ini bisa dimaknai sebagai aktivitas untuk ikut mendukung program-program kebaikan bagi manusia dan lingkungan ataupun ikut serta mencegah timbulnya kerusakan dimuka bumi. 
Basir S, Alokasi Dana CSR Sebagai Variabel Moderasi Antara...

\section{PENUTUP}

\section{Kesimpulan}

Penelitian ini dilakukan untuk menguji apakah pengaruh alokasi dana Corporate Social Responsibility yang diukur dean logarithm natural dapat mempengaruhi Good Corporate Governance terhadap nilai perusahaan. Berdasarkan hasil penelitian maka dapat ditarik kesimpulan sebagai berikut:

1) Good Corporate Governance menunjukkan secara langsung berpengaruh signifikan terhadap nilai perusahaan yang menggambarkan semakin baik Tata kelola suatu perusahaan maka nilai perusahaan juga akan semakin baik.

2) Variabel alokasi dana Corporate Social Responsibility mampu memoderasi Good Corporate Governance dan nilai perusahaan karena hal ini mengindikasikan bahwa semakin baik perusahaan melaksanakan corporate social responsibility (CSR) dan good corporate governance (GCG) terhadap masyarakat maupun sumber daya manusia serta pemegang saham akan dapat meningkatkan nilai perusahaan.

\section{Saran}

Berdasarkan hasil penelitian, penulis memberikan rekomendasi saran sebagai berikut :

1) Penelitian selanjutnya diharapkan menambahkan variabel lain, tidak hanya good corporate governance (GCG) dan nilai perusahaan. penambahan sampel dan tahun yang lebih lama.

2) Bagi investor hasil penelitian yang berhubungan dengan profitbilitas dan struktur modal perlu ditinjau kembali, agar investor dapat lebih jeli melihat sejauh mana tingkat perkembangan perusahaan dan dapat membandingkan dengan perusahaan yang lain.

3) Bagi perusahaan yang tergolong dalam perusahaan yang banyak mengeluarkan dampak limbah, seharusnya lebih memperhatikan lingkungan sekitar agar investor tertarik dan dana CSR sebagai variabel moderasi yang dikeluarkan tetap dapat memaksimalkan serta image perusahaan lebih baik di mata masyarakat

\section{REFERENSI}

Al-Quran

Alfredo Mahendra.2011 .Pengaruh Kinerja Keuangan terhadap Nilai Perusahaan (kebijakan Dividen Sebagai Variabel Moderating) Pada Perusahaan Manufaktur Di $B E I$. Universitas Udayana.

Arfiyanty dan Basuki. 2015. Pengaruh Corporate Governance Perception Index Dan Profitabilitas Perusahaan Terhadap Nilai Perusahaan. Jurnal Ekonomi dan Bisnis Undip

Basir. S. 2015. Motivasi Struktur Modal dan Nilai Perusahaan. Disertasi. Universitas Brawijaya Malang. Tidak Dipublikasikan.

Brigham, Eugene F dan Houston. 2006. Fundamental of FinancialManagement: Dasar-Dasar Manajemen Keuangan. Edisi 10. Jakarta: Salemba Empat.

Epstein, Marc. J dan Freedman, Martin. 1994. " Social Disclosure and the Individual Investor." JournalAccounting, Auditing \& Accountability, Vol. 7, No.4

Haruman, Tendi. 2008. Pengaruh Struktur Kepemilikan Terhadap Keputusan 
Keuangan dan Nilai Perusahaan. Simposium Nasional Akuntansi XI,Pontianak

Kusumadilaga, Rimba. 2010. Pengaruh Corporate Social Responsibility terhadap Nilai Perusahaan dengan Profitabilitas sebagai Variabel Moderating (studi empiris pada perusahaan manufaktur yang terdaftar di bursa efek indonesia). Skripsi . Universitas Diponegoro Semarang.

Martono dan D. Agus Harjito. 2005. Manajemen Keuangan. Penerbit Ekonisia: Yogyakarta.

Martono dan D. Agus Harjito. 2003. Manajemen Keuangan. Penerbit Ekonisia: Yogyakarta.

Monks R, Minow, N, "Watching the Watchers: Corporate Governance for the 21 st Century", Cambridge, Blackwell, 1996

Shleifer, A dan R. W.Vishny. 1997. A survey of corporate governance. The Journal of Finance. 52 (2): 737 783

Susanti, Rika. 2010. Analisis Faktor-Faktor Yang Berpengaruh Terhadap Nilai Perusahaan (Studi Kasus pada Perusahaan Go Public yang Listed Tahun 2005- 2008). Skripsi. Universitas Diponegoro Semarang www.kilasberita.com. "Bank Kebobolan Kredit Fiktif Miliaran Rupiah". Diakses 25 November 2017

www.liputan6.com . "Mantan Direktur Bank Divonis Tujuh Tahun Penjara”. Diakses 25 November 2017
Simorangkir. 2003. Etika: Bisnis, Jabatan dan Perbankan. Jakarta: Rineka cipta.

Kiroyan, Noke. 2006. "Good Corporate Governance (GCG) dan Corporate Social 99 Responsibility (CSR) Adakah Kaitan di Antara Keduanya?". Jurnal Economics Business Accounting Review. Ed. September-Desember: 45-58

Mahmud. (2011). Metode Penelitian Pendidikan. Bandung: Pustaka Setia.

Jensen, M.C., and W. H. Meckling. 1976. "Theory of The Firm: Manajerial Behaviour, Agency Cost, and Ownership Structure". Journal of Financial and Economics, 3, 305360.

Atmaja, Lukas Setia. 2008. Teori dan Praktik Manajemen Keuangan. Yogyakarta: CV. ANDI OFFSET.

Warsono, Sony \& Fitri amalia.2009.Corporate Governance Concept and Model.Yogyakarta: Center for Good Corporate Governance FE UGM

Zarkasyi, Moh Wahyudin. 2008. Good Corporate Governance Pada Badan Usaha Manufaktur Perbankan dan Jasa Keuangan Lainnya. Bandung : Penerbit Alfabeta

www.idx.com

WWW.sgX.com

Www.investing.com

www.duniainvestasi.com 